\title{
Effects of Rutin on Testicular Antioxidant Enzymes and Lipid Peroxidation in Rats
}

\author{
Rahmat Ali Khan ${ }^{1 *}$, Muhammad Rashid Khan², Mushtaq Ahmed ${ }^{1}$, Mir Sadiq Shah', Shoiab Ur \\ Rehman', Jahangir Khan³, Masroor Husain', Farman Ali Khan', Muhammad Mohibullah Khan', \\ Muhammad Shahzad Shifa ${ }^{6}$
}

\author{
1Department of Biotechnology, Faculty of Biological Sciences, University of Science and Technology Bannu, Khyber Pakutunkhwa, \\ PAKISTAN. \\ ${ }^{2}$ Department of Biochemistry, Faculty of Biological Sciences, Quaid-i-Azam University Islamabad, PAKISTAN. \\ ${ }^{3}$ Department of Pharmacy, University of Malakand, Chakdara Dir, Khyber Pakutunkhwa, PAKISTAN. \\ ${ }^{4}$ Department of Biochemistery, Abdul Wali Khan University Mardan, 23200, Khyber Pakutunkhwa, PAKISTAN. \\ ${ }^{5}$ Department of Plant Breeding and Genetics \\ ${ }^{6}$ Department of Physics Government College University Faisalabad
}

\begin{abstract}
Background: Rutin, a polyphenolic flavonoid, possesses antioxidant and hypoglycemic effects. Objective: The present study was conducted to check the effect of rutin on serum reproductive hormonal level and sperm concentration in male rat. Methods: 30 rats were equally divided into 3 groups (10 rats per group). Group I was control (untreated), group II was given rutin $50 \mathrm{mg} / \mathrm{kg}$ bw while group III was given $100 \mathrm{mg} /$ $\mathrm{kg}$ bw intragastric twice a week for four weeks respectively. The effect of rutin on antioxidant enzymes (POD, SOD, GSHpx, GST, GSR), glutathione contents and TBARS contents were checked. Results: The results revealed that rutin caused significant gain in body weight, antioxidant enzymes (POD, SOD, GSHpx, GST, GSR), glutathione contents, with significant $(P<0.01)$ decrease in thiobarbituric acid reactive substance (TBARS) concentrations. Conclusion: It may be concluded that rutin may be promising as a natural therapeutic agent in male reproductive dysfunction.
\end{abstract}

Key words: Rutin, TBARS contents, Antioxidant enzymes, Flavonoids, Catalase.

\section{INTRODUCTION}

Traditional medicine is the sum of knowledge, skills and practices based on theories, beliefs and experiences, indigenous to different cultures that are used to maintain health, as well as to prevent, diagnose, improve or treat physical and mental illness. ${ }^{1}$ Virtually every illness has a remedy made from concoctions of various parts of the useful flora used for gastro- intestine disorders, cardiovascular, respiratory or nervous diseases as well as fertility problems such as sexual dysfunctions, which is common in $31 \%$ of men. ${ }^{2}$ Traditional medicine or folk medicine practice is based on the use of medicinal plants and their extracts. Flavonoids are main constituents of plants and more than 4000 polyphenilc flavonoids are used as a component of human diet. $^{3}$ Flavonoids acquire an astonishing range of activities accredited, at slightest moderately, to their scavenging behavior of reactive oxygen species. ${ }^{4,5}$ Flavonoids are implicated to exercise valuable effect in a range of disorders including infertility and oxidative stress. ${ }^{6}$ The most commonly occurring dietary flavonoids such as rutin, hypersoid, quercetin, catchine and myricetin exhibit an extensive range of activities, including antimicrobial, anti-inflammatory and anticancer. ${ }^{7,8}$ Rutin is an important source of dietary flavonoid. ${ }^{4}$ It has been distributed in many foods such as onion, apples and in buck wheat, many vegetables, fruits and plant-derived beverages such as tea and wine. Rutin works as scav-
Submission Date: 13-12-2016; Revision Date: 24-01-2017; Accepted Date: 15-02-2017

DOI: 10.5530/ijper.51.3.69 Correspondence: Dr. Rahmat Ali Khan, Department of Biotechnology, Biotech, UST Bannu, KP,PAKISTAN. Phone: 92928633425 Fax: 92519205753 E-mail: rahmatgenetics@ gmail.com

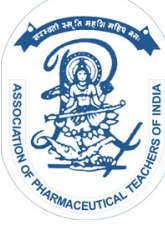

www.ijper.org 
enger of ROS by donating hydrogen atoms to peroxy radicals, superoxide anions, singlet oxygen and hydroxyl radicals and as terminator and chelators of metal ions that are capable of oxidizing lipid peroxidation. ${ }^{7}$ Rutin has been shown to function as anticancer, antiviral, antibacterial, anti-inflammatory and used as a therapeutic in cardiovascular and neurodegenerative disorders which is the result of its high radical scavenging activity and antioxidant capacity. ${ }^{6}$ Additionally results presented in different studies suggested that rutin alters signal transduction, causes activation of transcription factors, gene expression and may also protect DNA by interacting with carcinogens that have escaped detoxification processes. ${ }^{8}$ These studies suggest that potential role for dietary intake of rutin containing foods in lowering the risk of certain pathophysiologies that have been associated with free radical-mediated diseases. The present study is therefore aimed at investigating the effect of rutin on hormonal secretion in Sprague-Dawley male rat.

\section{EXPERIMENTAL}

\section{Chemicals}

Rutin, Reduced glutathione (GSH), oxidized glutathione (GSSG), glutathione reductase, gamma-glutamyl p-nitroanilide, glycylglycine, bovine serum albumin (BSA), 1,2-dithio-bis nitro benzoic acid (DTNB), 1-chloro-2,4-dinitrobenzene (CDNB), reduced nicotinamide adenine dinucleotide phosphate (NADPH), Flavine adenine dinucleotide (FAD), glucose-6-phosphate, Tween-20, 2,6-dichlorophenolindophenol, thiobarbituric acid (TBA), picric acid, sodium tungstate, sodium hydroxide, trichloroacetic acid (TCA) and perchloric acid (PCA) were purchased from Sigma Chemicals Co. St. Louis, USA.

\section{Animals and treatment}

Six-week-old male Sprague-Dawley rats weighing $180 \pm 5$ $\mathrm{g}$ were provided with food and water ad libitum and kept at $20-22^{\circ} \mathrm{C}$ on a 12 -h light-dark cycle. All experimental procedures involving animals were conducted in accordance with the guidelines of National Institutes of Health (NIH guidelines Islamabad, Pakistan). The study protocol was approved by Ethical Committee of Quaid-i-Azam University, Islamabad. The rats were acclimatized to laboratory condition for 7 days before commencement of experiment.

The following experimental groups $(\mathrm{n}=10$ rats per group) were studied.

Group I: (control); the animals were remained untreated
Group II: animals were treated with $50 \mathrm{mg} / \mathrm{kg}$ bw rutin, intragastric twice a week for four weeks

Group III: was treated with $100 \mathrm{mg} / \mathrm{kg}$ bw rutin, intragastric twice a week for four weeks

After the completion of dosages rats were dissected. Half of tissues were treated with liquid nitrogen and stored at $-80^{\circ} \mathrm{C}$ for further analysis.

Assessment of antioxidant profile

Testicular tissue was homogenized in 10 volume of 100 mmol $\mathrm{KH}_{2} \mathrm{PO}_{4}$ buffer containing $1 \mathrm{mmol}$ EDTA (pH 7.4) and centrifuged at $12,000 \times \mathrm{g}$ for $30 \mathrm{~min}$ at $4^{\circ} \mathrm{C}$. The supernatant was collected and used for enzymatic studies. Protein concentration of testis supernatant was determined by the method of Lowry et al. ${ }^{9}$ using crystalline BSA as standard.

\section{Catalase assay (CAT)}

CAT activities were determined by the method of Chance and Maehly ${ }^{10}$ with some modifications. The reaction solution of CAT activities contained: $2.5 \mathrm{ml}$ of $50 \mathrm{mmol}$ phosphate buffer (pH 5.0), $0.4 \mathrm{ml}$ of $5.9 \mathrm{mmol}$ $\mathrm{H}_{2} \mathrm{O}_{2}$ and $0.1 \mathrm{ml}$ enzyme extract. Changes in absorbance of the reaction solution at $240 \mathrm{~nm}$ were determined after one min. One unit of CAT activity was defined as an absorbance change of 0.01 as units/min.

\section{Superoxide dismutase assay (SOD)}

SOD activity was estimated by the method of Kakkar et al. ${ }^{11}$ Reaction mixture of this method contained: 0.1 $\mathrm{ml}$ of phenazine methosulphate $(186 \mu \mathrm{mol}), 1.2 \mathrm{ml}$ of sodium pyrophosphate buffer (0.052 mmol; $\mathrm{pH} 7.0), 0.3$ $\mathrm{ml}$ of supernatant after centrifugation $(1500 \times \mathrm{g}$ for 10 min followed by $10000 \times \mathrm{g}$ for $15 \mathrm{~min}$ ) of testis homogenate was added to the reaction mixture. Enzyme reaction was initiated by adding $0.2 \mathrm{ml}$ of $\mathrm{NADH}$ (780 $\mu \mathrm{mol})$ and stopped after $1 \mathrm{~min}$ by adding $1 \mathrm{ml}$ of glacial acetic acid. Amount of chromogen formed was measured by recording color intensity at $560 \mathrm{~nm}$. Results are expressed in units/mg protein.

\section{Estimation of lipid peroxidation assay (TBARS)}

The assay for lipid peroxidation was carried out with modified method of Iqbal et al. ${ }^{12}$ The reaction mixture in a total volume of $1.0 \mathrm{ml}$ contained: $0.58 \mathrm{ml}$ phosphate buffer (0.1 mol; pH 7.4), $0.2 \mathrm{ml}$ homogenate sample, 0.2 $\mathrm{ml}$ ascorbic acid $(100 \mathrm{mmol})$, and $0.02 \mathrm{ml}$ ferric chloride $(100 \mathrm{mmol})$. The reaction mixture was incubated at $37^{\circ} \mathrm{C}$ in a shaking water bath for $1 \mathrm{~h}$. The reaction was stopped by addition of $1.0 \mathrm{ml} 10 \%$ trichloroacetic acid. Following addition of $1.0 \mathrm{ml} 0.67 \%$ thiobarbituric acid, all the tubes were placed in boiling water bath for $20 \mathrm{~min}$ and then shifted to crushed ice-bath before cen- 
trifuging at $2500 \times \mathrm{g}$ for $10 \mathrm{~min}$. The amount of malonaldehyde formed in each of the samples was assessed by measuring optical density of the supernatant at 535 $\mathrm{nm}$ using spectrophotometer against a reagent blank. Tetramethoxypropane was used as an external standard. The results were expressed as nmol of TBARS/min/ $\mathrm{mg}$ tissue protein.

\section{Glutathione-S-transferase assay (GST)}

The reaction mixture of glutathione-S-transferase activity consisted of $1.475 \mathrm{ml}$ phosphate buffer $(0.1 \mathrm{~mol}$, $\mathrm{pH}$ 6.5), $0.2 \mathrm{ml}$ reduced glutathione $(1 \mathrm{mmol}), 0.025$ $\mathrm{ml}(\mathrm{CDNB} ; 1 \mathrm{mmol})$ and $0.3 \mathrm{ml}$ of tissue homogenate in a total volume of $2.0 \mathrm{ml}$. The changes in the absorbance were recorded at $340 \mathrm{~nm}$ and enzymes activity was calculated as nmol CDNB conjugate formed/min/ $\mathrm{mg}$ protein using a molar extinction coefficient of $9.6 \times$ $10^{3} \mathrm{M}^{-1} \mathrm{~cm}^{-1} \cdot{ }^{13}$

\section{Glutathione reductase assay (GSR)}

Glutathione reductase activity was determined with the protocol of Carlberg and Mannervik. ${ }^{14}$ The reaction mixture consisted of $1.65 \mathrm{ml}$ phosphate buffer: (0.1 mol; pH 7.6), $0.1 \mathrm{ml}$ EDTA (0.5 mmol), $0.05 \mathrm{ml}$ oxidized glutathione (1 mmol), $0.1 \mathrm{ml} \mathrm{NADPH}(0.1 \mathrm{mmol})$ and $0.1 \mathrm{ml}$ of homogenate in a total volume of $2 \mathrm{ml}$. Enzyme activity was quantitated at $25^{\circ} \mathrm{C}$ by measuring disappearance of NADPH at $340 \mathrm{~nm}$ and was calculated as nmol NADPH oxidized $/ \mathrm{min} / \mathrm{mg}$ protein using molar extinction coefficient of $6.22 \times 10^{3} \mathrm{M}^{-1} \mathrm{~cm}^{-1}$.

\section{Glutathione peroxidase assay (GSH-px)}

Glutathione peroxidase activity was assayed by the method of Mohandas et al..$^{15}$ The reaction mixture consisted of $1.49 \mathrm{ml}$ phosphate buffer ( $0.1 \mathrm{~mol}$; $\mathrm{pH} 7.4)$, $0.1 \mathrm{ml}$ EDTA ( $1 \mathrm{mmol}), 0.1 \mathrm{ml}$ sodium azide $(1 \mathrm{mmol})$, $0.05 \mathrm{ml}$ glutathione reductase $(1 \mathrm{IU} / \mathrm{ml}), 0.05 \mathrm{ml} \mathrm{GSH}$ (1 mmol), $0.1 \mathrm{ml} \mathrm{NADPH}(0.2 \mathrm{mmol}), 0.01 \mathrm{ml} \mathrm{H}_{2} \mathrm{O}_{2}$ $(0.25 \mathrm{mmol})$ and $0.1 \mathrm{ml}$ of homogenate in a total vol-

\begin{tabular}{|c|c|c|c|}
\hline \multicolumn{4}{|c|}{ Table 1: Effect of rutin on body weight, testis weight, } \\
relative testis weight in rat \\
\hline \multirow{2}{*}{ Treatment } & Tissue & Relative testis & $\%$ Body \\
\cline { 2 - 4 } & weight $(\mathbf{g})$ & weight $(\mathbf{g})$ & weight $\mathbf{( g )}$ \\
\hline Control & $7.1 \pm 0.16 \mathrm{a}$ & $0.034 \pm 0.016 \mathrm{a}$ & $6.8 \pm 0.9 \mathrm{a}$ \\
\hline $\begin{array}{c}50 \mathrm{mg} / \mathrm{kg} \mathrm{bw} \\
\text { rutin }\end{array}$ & $7.5 \pm 0.16 \mathrm{a}$ & $0.035 \pm 0.001 \mathrm{a}$ & $7.0 \pm 1.6 \mathrm{a}$ \\
\hline $\begin{array}{c}100 \mathrm{mg} / \mathrm{kg} \mathrm{bw} \\
\text { rutin }\end{array}$ & $7.8 \pm 0.08 \mathrm{a}$ & $0.038 \pm 0.004 \mathrm{a}$ & $7.1 \pm 1.0 \mathrm{a}$ \\
\hline
\end{tabular}

Each value in the table is represented as mean $\pm S D(n=10)$

Means not sharing the same letter are significantly different (LSD) at $P<0.01$ probability level in each column ume of $2 \mathrm{ml}$. The disappearance of NADPH at $340 \mathrm{~nm}$ was recorded at $25^{\circ} \mathrm{C}$. Enzyme activity was calculated as $\mathrm{nmol} \mathrm{NADPH}$ oxidized/min/mg protein using molar extinction coefficient of $6.22 \times 10^{3} \mathrm{M}^{-1} \mathrm{~cm}^{-1}$.

\section{Reduced glutathione assay (GSH)}

$1.0 \mathrm{ml}$ sample of homogenate was precipitated with 1.0 $\mathrm{ml}$ of $(4 \%)$ sulfosalicylic acid. The samples were kept at $4^{\circ} \mathrm{C}$ for $1 \mathrm{~h}$ and then centrifuged at $1200 \times \mathrm{g}$ for 20 min at $4^{\circ} \mathrm{C}$. The total volume of $3.0 \mathrm{ml}$ assay mixture contained: $0.1 \mathrm{ml}$ filtered aliquot, $2.7 \mathrm{ml}$ phosphate buffer (0.1 mol; pH 7.4) and $0.2 \mathrm{ml} \mathrm{DTNB} \mathrm{(100} \mathrm{mmol).}$ The yellow color developed was read immediately at 412 $\mathrm{nm}$ on a SmartSpecTM plus Spectrophotometer. It was expressed as $\mu \mathrm{mol} \mathrm{GSH} / g$ tissue. ${ }^{16}$

\section{Statistical analysis}

The values were expressed as the mean \pm SEM for the 10 rats in each group. Differences between groups were assessed by one-way analysis of variance (ANOVA) using the Statistical Package for Social Sciences (SPSS) software package for Windows (version 13.0). Post hoc testing was performed for intergroup comparisons using the least significant difference (LSD) test. A value corresponding to $\mathrm{P}<0.05$ was deemed to be statistically significant.

\section{RESULTS}

Effect of rutin on body weight, testis weight, relative testis weight in rat

Body weight play important role in assessment of oxidative dysfunction. The effects of rutin on body weight, testis weight and relative testis weight are shown in Table 1. Administration of rutin non-significantly $(p<0.05)$ improved body weight, testis weight and relative testis weight compare to control group.

\begin{tabular}{|c|c|c|c|}
\hline \multicolumn{4}{|c|}{ Table 2: Effect of rutin on tissue protein, activities of } \\
CAT and SOD in male rat \\
\hline Treatment & $\begin{array}{c}\text { Protein }(\mathbf{\mu g} / \\
\text { mg tissue) }\end{array}$ & CAT (U/min) & SOD (U/min) \\
\hline Control & $82.5 \pm 2.0 \mathrm{a}$ & $60.8 \pm 1.0 \mathrm{a}$ & $50.6 \pm 1.6 \mathrm{a}$ \\
\hline $\begin{array}{c}50 \mathrm{mg} / \mathrm{kg} \\
\mathrm{bw} \mathrm{rutin}\end{array}$ & $96.0 \pm 1.9 \mathrm{~b}$ & $83.1 \pm 2.1 \mathrm{~b}$ & $71.6 \pm 3.09 \mathrm{a}$ \\
\hline $\begin{array}{c}100 \mathrm{mg} / \mathrm{kg} \\
\text { bw rutin }\end{array}$ & $102.5 \pm 2.3 \mathrm{~b}$ & $100.4 \pm 2.0 \mathrm{~b}$ & $85.2 \pm 3.1 \mathrm{~b}$ \\
\hline
\end{tabular}

Each value in the table is represented as mean $\pm S D(n=10)$

Means not sharing the same letter are significantly different (LSD) at $P<0.01$ probability level in each column 


\begin{tabular}{|c|c|c|c|c|c|}
\hline Treatment & $\begin{array}{c}\text { GSH-Px (nM/mg } \\
\text { protein) }\end{array}$ & $\begin{array}{c}\text { GSR (nM/min } / \mathrm{mg} \\
\text { protein) }\end{array}$ & $\begin{array}{l}\text { TBARS (nM/ min/ } \\
\text { mgprotein) }\end{array}$ & GSH $(\mu \mathrm{M} / \mathrm{g}$ tissue $)$ & $\begin{array}{l}\mathrm{GST}(\mathrm{nM} / \mathrm{min} / \mathrm{mg} \\
\text { protein) }\end{array}$ \\
\hline Control & $120 \pm 2.3^{a}$ & $702.3 \pm 1.6^{a}$ & $8.3 \pm 0.3^{a}$ & $3.7 \pm 0.010^{a}$ & $160 \pm 2.3^{a}$ \\
\hline $50 \mathrm{mg} / \mathrm{kg}$ bw rutin & $131 \pm 1.8^{a}$ & $98.2 \pm 1.4^{b}$ & $5.0 \pm 0.03^{b}$ & $5.8 \pm 0.014^{b}$ & $176 \pm 3.8^{b}$ \\
\hline $100 \mathrm{mg} / \mathrm{kg}$ bw rutin & $140 \pm 2.9^{b}$ & $99.8 \pm 1.5^{b}$ & $4.3 \pm 0.01 \mathrm{~b}$ & $5.9 \pm 0.075^{b}$ & $179 \pm 2.5^{b}$ \\
\hline
\end{tabular}

\section{Effect of rutin on tissue protein, activities of CAT and SOD in male rat}

Antioxidant enzymes are very important for detoxification of reactive oxygen species (ROS) and maintaining cellular balance. The effects of various concentrations of rutin on tissue soluble protein, CAT and SOD are shown in Table 2. Oral administration of 50 and 100 $\mathrm{mg} / \mathrm{kg}$ body weight rutin showed marked improvement on the antioxidant enzyme level as compare to control group behave as an excellent antioxidant.

\section{Effect rutin on testis GST, GSH-Px, GSR, GSH and TBARS in male rat}

Rutin play a crucial role on the activity of secondary defense level of antioxidant enzymes for improvement of sound health. The effects of various concentrations of rutin on GSH-Px, GSR, GST, GSH and TBARS are shown in Table 3. Oral administration of 50 and $100 \mathrm{mg} / \mathrm{kg}$ body weight showed marked increment on the activity of enzyme and decreased testicular tissue lipid peroxidation i.e. TBARS comparatively to control group.

\section{DISCUSSION}

In this investigation, results revealed that rutin a polyphenolic compound is caused changes in body weight, testis weight and relative testis weight (Table 1), in agreement with previous studies. ${ }^{17}$ It has been shown that increased testis weight reflects the increment of lipid peroxidation that in turn related to fatty accumulation and alteration of weight. ${ }^{18}$ Antioxidant enzymes play important role in detoxification of oxidative damages constitute a mutually supportive team of defense against reactive oxygen species (ROS). Activity of antioxidant and phase II metabolizing enzymes were reduced due to decreased content of GSH. Depletion of antioxidant responses has been implicated with fertility. Present study revealed that the activities of antioxidant enzymes including glutathione-S-transferase, glutathione reductase, superoxide dismutase, catalase, glutathione peroxidase and glutathione contents was significantly reduced in rats (Table $2 \& 3$ ) which pos- sesses infertility and reproductive dysfunction. ${ }^{19}$ Similar effects were observed in reports of Yousef et al. ${ }^{20}$ and Khattab et al. ${ }^{21}$

\section{CONCLUSION}

This study provided the scientific proof that diet containing rutin is useful for reproductive dysfunction in male via increasing their antioxidant defense level and decreasing lipid peroxidation.

\section{CONFLICT OF INTEREST}

We are thankful for Vice Chancellor for provision of Research facilities.

\section{ABBREVIATION USED}

None

\section{REFERENCES}

1. Acarya D, Shrivastava A. Indigeneous Herbal Medicine. Tribal Formulations and Traditional Herbal Practices, Aavishka Publisher Distributor, Jaipur, India. ISBN: 9788179 102527. 2008;40

2. Brock GB, McMahon CG, Chen KK. Efficacy and safety of tadalafil for the treatment of erectile dysfunction: Results of integrated analyses. J Urol. 2002;168(4):1332-6.

3. Noroozi M, Angerson WJ, Lean ME. Effects of flavonoids and vitamin C on oxidative DNA damage to human lymphocytes. American J Clin Nutr. 1998;67(6):1210-8.

4. Middleton EJ, Kandaswami C, Theoharides TC. The effects of plant flavonoids on mammalian cells: implications for inflammation, heart disease, and cancer. Pharmacol Rev. 2000;52(4):673-751.

5. Williams RJ, Spencer JP, Rice-Evans C. Flavonoids: Antioxidants or signaling molecules?. Free Rad Biol Med. 2004;36:838-49. doi: 10.1016/j. freeradbiomed.2004.01.001.

6. Kampkötter A, Nkwonkam CG, Zurawski RF, Timpel C, Chovolou Y, Wätjen $\mathrm{W}$, et al. Investigations of protective effects of the flavonoids quercetin and rutin on stress resistance in the model organism Caenorhabditis elegans. Toxicology. 2007;234(1):113-23.

7. Hanasaki Y, Ogawa S, Fukui S. The correlation between active oxygen scavenging. Free Radic Biol Med. 1994;16:845-50.

8. Srinivasan M, Rukkumani R, Ram SA, Menon VP. Ferulic acid, a natural protector against carbon tetrachloride induced toxicity. Fundam Clin Pharmacol. 2005;19(4):491-6.

9. Lowry OH, Rosebrough NJ, Farr AL, Randall RJ. Protein measurement with the Folin phenol reagent. J Biol Chem. 1951;193(1):265-75

10. Chance B, Maehly A. Assay of catalases and peroxidases. Methods in Enzymol. 1955;2:764-75. 
11. Kakkar P, Das B, Viswanathan P. A modified spectrophotometric assay of superoxide dismutase. Indian J Biochem Biophys. 1984;21:130-2.

12. Iqbal M, Sharma SD, Zadeh HR, Hasan N, Abdulla M, Athar M. Glutathione metabolizing enzymes and oxidative stress in ferric nitrilotriacetate (Fe-NTA) mediated hepatic injury. Redox Report. 1996;2(6):385-91.

13. Habig WH, Pabst MJ, Jakoby WB. Glutathione-S-transferases: The first enzymatic step in mercapturic acid formation. J Biol Chem. 1974;249:7130-9.

14. Carlberg I, Mannervik EB. Glutathione level in rat brain. J Biol Chem. 1975;250:4475-80.

15. Mohandas J, Marshal JJ, Duggin GG, Horvath JS, Tiller DJ. Differential distribution of glutathione and glutathione-related enzymes in rabbit kidney. Possible implications in analgesic nephropathy. Biochem Pharmacol Biochem Pharmacol. 1984;33(11):1801-7.

16. Jollow DJ, Mitchell JR, Zampaglione N, Gillete JR. Bromobenzene induced liver necrosis. Protective role of glutathione and evidence for 3,4-bromobenzene oxide as a hepatotoxic metabolite. Pharmacol. 1974;11(3):151-69.

17. Cadenas S, Barja G. Resveratrol, melatonin, vitamin E and PBN protect against renal oxidative DNA damage induced by kidney carcinogen $\mathrm{KBrO} 3$. Free Rad Biol Med. 1999;26(11):1531-7.

18. Kurokawa Y, Maekawa A, Takahashi M, Hayashi Y. Toxicity and carcinogenicity of potassium bromate-a new renal carcinogen. Envirn Health Persp. 1990;87:309-35.

19. Al-Saaidi JAA, Al-Khuzai ALD, Al-Zobaydi NFH. Effect of alcoholic extract ofNigella sativaon fertility in male rats. Iraqi J Vet Sci. 2009;23(SuppI II):1231220.

20. Yousef MI, Salama AF. Propolis protection fromreproductive toxicitycaused by aluminium chloride inmalerats. Food and Chem Toxicol. 2009;47(6):116875

21. Khattab IKF. Histological and ultrastructural studies on the testis ofrat after treatment with aluminium chloride. Austr J Basic Appl Sci. 2007;1(1):63-72.

\section{PICTORIAL ABSTRACT}

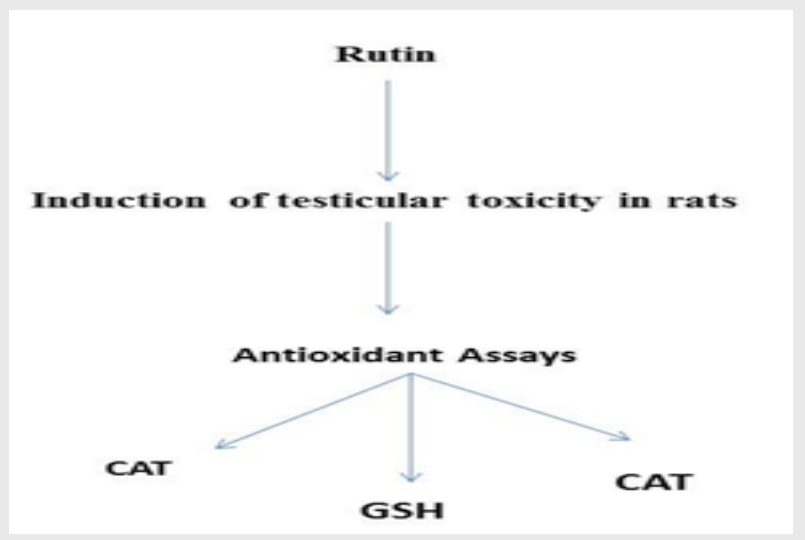

\section{SUMMARY}

- Rutin, a polyphenolic flavonoid, possesses antioxidant and hypoglycemic effects.

- In the present study was conducted to check the effect of rutin on serum reproductive hormonal level and sperm concentration in male rat. Rats were equally divided into 3 groups. The effect of rutin on antioxidant enzymes (POD, SOD, GSHpx, GST, GSR), glutathione contents and TBARS contents were checked which showed potent results due to the presence of bioactive constituents.

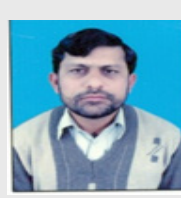

\section{ABOUT AUTHORS}

Dr. Rahmat Ali Khan (Biochemist): Main area of research Pharmacology and Toxicology. Dr. Khan is also focusing on the Pharmacological potentials of medicinal plants.

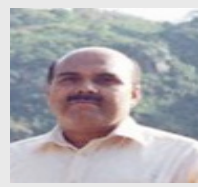

Dr. Muhammad Rashid Khan: Working on the Pharmacological potentials of medicinal plants

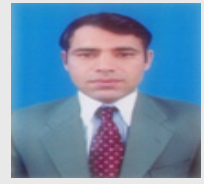

Dr. Mushtaq Ahmed: Working on the Pharmacological potentials of medicinal plants

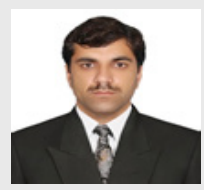

Dr. Shoaib ur Rehman: Working as an assistant professor (Molecular Biology) in the Department of biotechnology university of Science and Technology Bannu, KPP, Pakistan.

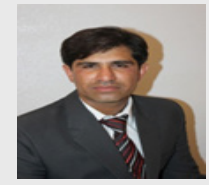

Dr. Mir Sadiq Shah (Microbiologist): Main area of research is Clinical \& Food Microbiology. Dr. Shah is also focusing on the antimicrobial potentials of medicinal plants. 


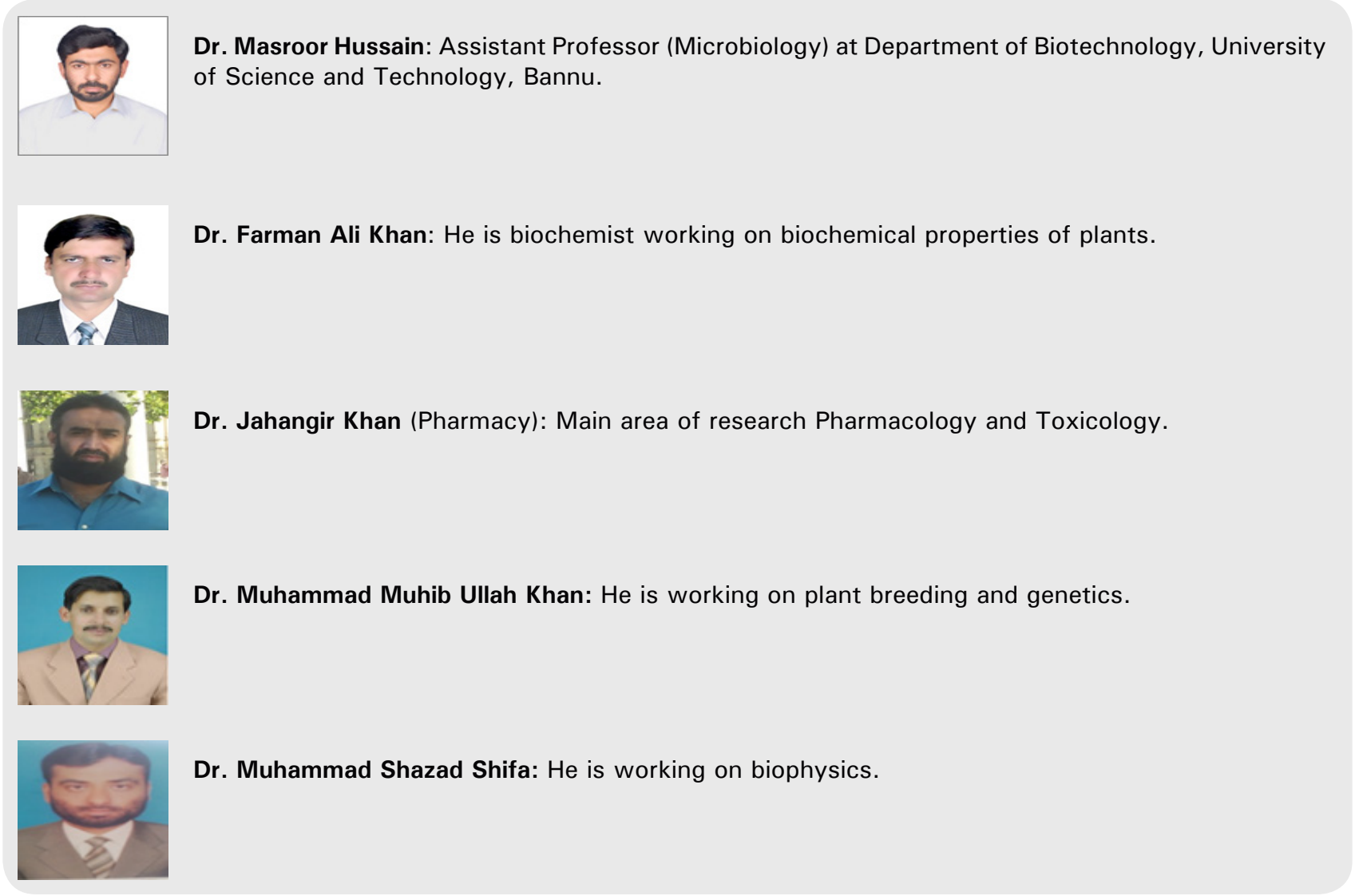

Cite this article: Khan RA, Khan MR, Ahmed M, Shah MS, Rehman SU, Khan J, Husain M, Khan FA, Khan MM, Shifa MS. Effects of rutin on testicular antioxidant enzymes and lipid peroxidation in rats. Indian $\mathrm{J}$ of Pharmaceutical Education and Research. 2017;51(3):412-7. 